\title{
REVIEW
}

\section{Human parvovirus B19: A review}

\author{
L. D. ROGO ${ }^{1,2,3}$, T. MOKHTARI-AZAD ${ }^{2,3}$, M. H. KABIR ${ }^{4,5}$, F. REZAEI ${ }^{2,3^{*}}$
}

\begin{abstract}
${ }^{1}$ Department of Medical Laboratory Science, Faculty of Medicine, Bayero University Kano, Nigeria; ${ }^{2}$ Department of Medical Virology, School of Public Health, Tehran University of Medical Sciences, Tehran, Iran; ${ }^{3}$ Department of Medical Virology, School of Public Health, Tehran University of Medical Sciences International Campus, Tehran, Iran; ${ }^{4}$ Department of Medical Pathobiology, School of Public Health, Tehran University of Medical Sciences International Campus, Tehran, Iran; ${ }^{5}$ Department of Immunology, Faculty of Medical Laboratory Sciences, Usmanu Danfodiyo University Sokoto, Nigeria
\end{abstract}

\author{
Received January 27, 2014; accepted July 30, 2014
}

\begin{abstract}
Summary. - Parvovirus B19 (B19V) is a small non-enveloped single-stranded DNA (ssDNA) virus of the family Parvoviridae, the subfamily Parvovirinae, the genus Erythrovirus and Human parvovirus B19 type species. It is a common community-acquired respiratory pathogen without ethnic, socioeconomic, gender, age or geographic boundaries. Moreover, the epidemiological and ecological relationships between human parvovirus B19, man and environment have aroused increasing interest in this virus. B19V infection is associated with a wide spectrum of clinical manifestations, some of which were well established and some are still controversial, however, it is also underestimated from a clinical perspective. B19V targets the erythroid progenitors in the bone marrow by binding to the glycosphingolipid globoside (Gb4), leading to large receptor-induced structural changes triggering cell death either by lysis or by apoptosis mediated by the nonstructural (NS) 1 protein. The pattern of genetic evolution, its peculiar properties and functional profile, the characteristics of its narrow tropism and restricted replication, its complex relationship with the host and its ample pathogenetic potential are all topics that are far from a comprehensive understanding. The lack of efficient adaptation to in vitro cellular cultures and the absence of animal models have limited classical virological studies and made studies on B19V dependent on molecular biology. The present review looks at the nature of this virus with the view to provide more information about its biology, which may be useful to the present and future researchers.
\end{abstract}

Keywords: human parvovirus B19; respiratory pathogen; biology; genome; fifth disease; transient aplastic crisis; anemia

\section{Contents:}

1. Introduction

2. Morphological criteria of B19 virus

3. Functional genomics of B19 virus

4. B19 virus receptor and internalization

${ }^{*}$ Corresponding author. E-mail: rezaie@tums.ac.ir; phone: +982188982343 .

Abbreviations: $\mathrm{B} 19 \mathrm{~V}=$ parvovirus B19; Gb4 = glycosphingolipid globoside; IL-6 = interleukin 6; IVIG = intravenous immunoglobulin $\mathrm{G} ; \mathrm{MHC}=$ major histocompatibility class; SF3-helicase $=$ superfamily 3 helicase; NS = nonstructural; TNF- $\alpha=$ tumor necrosis factor $\alpha$; VLPs = virus like particles; VP1 = viral protein 1 ; $\mathrm{VP} 2=$ viral protein 2
5. Epidemiology

6. Pathogenesis and immune response

7. Clinical manifestations and complications

8. Diagnosis

9. Treatment

10. Prevention and vaccine development

11. Conclusions

\section{Introduction}

Parvovirus B19 (B19V) is a small single-stranded DNA (ssDNA) virus of the family Parvoviridae, the subfamily 
Parvovirinae, the genus Erythrovirus and Human Parvovirus B19 type species (Meryl and Jeffrey, 2007; Servey et al., 2007; Kahn et al., 2008). It gained its name because it was discovered in well B19 of a large series of microtiter plates labeled in this way (Sabella and Goldfarb, 1999). It is divided into three genotypes - with subtypes (B19V, LaLi-like, and V9like), which have 10\% nt divergence (Nguyen et al., 1999; Hokynan et al., 2002; Servant et al., 2002; Molar-de Backer et al., 2012). While these genotypes generally cross-react serologically, detection by PCR amplification may require specific primers. The virus was first discovered in 1975 and first linked to human disease in 1981 (Cossart et al., 1975, 1981). Infection with parvovirus B19 causes several clinical syndromes (fifth disease, transient aplastic crisis, pure red cell aplasia, hydrops fetalis, glomerulopathy and anaemia in end stage renal disease) and may contribute to other illnesses (Cohen and Buckley, 1988; de Jong et al., 2011).

Infection with parvovirus is very common and occurs worldwide without ethnic or geographical boundary. Acquisition is often during childhood and continues at lower rates throughout adulthood, such that between 70 and $85 \%$ of adults show serologic evidence of past infection (Cohen and Buckley, 1988; Kelley et al., 2000). Infectivity shows seasonal variation in temperate climates, being more common in winter and spring. Transmission of infection usually occurs by inhalation of virus in aerosol droplets (Anderson et al., 1985). Infection can also be transmitted vertically from mother to fetus, through transfusion of blood products, bone marrow transplants, and solid-organ transplants (Jordan, 1996; Azzi et al., 1999; Heegard and Lamb, 2000; Broliden, 2001; Egbuna et al., 2006). The secondary attack risk for exposed household persons is about $50 \%$, and about half of that for classroom contacts (Young and Brown, 2004).

Symptoms characterized by low-grade fever, malaise, a "slapped cheek" facial rash, and later by the spread of a lacy maculopapular rash involving the trunk and limbs (Kelley et al., 2000). The rash normally disappears within 1 week, although recrudescences can occur for several months after emotional or physical stress or exposure to sunlight or heat (Musiani et al., 2005). Arthralgias and arthritis can occur in the setting of erythema infectiosum, but arthropathy is a more common manifestation of infection in adults, particularly in women (White et al., 1985). It typically manifests as sudden onset of symmetric polyarthralgia or polyarthritis with a rheumatoid-like distribution involving knees, wrists, ankles, and metacarpophalangeal joints. Although the joint symptoms are usually of brief duration, some do have prolonged symptoms that last weeks to years. Transient aplastic crisis as a result of B19 infection is of particular concern in patients with either decreased red blood cell production or increased turnover (e.g. hereditary spherocytosis, sickle cell disease) (Serjeant et al., 1993).
Antibodies are the hallmark of the adaptive immune response to B19V. In naïve individuals, B19V-specific antibodies are produced early after infection and are assumed to be able to neutralize viral infectivity and progressively lead to clearance of infection. IgM are produced first and can usually last about 3-6 months following infection, soon followed by production of IgG that is assumed to be long-lasting. IgA can also be detected in body fluids (Giorgio, 2013).

\section{Morphological criteria of B19 virus}

B19V was first identified tentatively as a parvovirus on the basis of morphology at the electron microscopy observation. Initial biochemical characterization of virions confirmed typical properties of parvoviruses, and their composition of two structural proteins, VP1 and VP2. The larger VP1 protein accounts for about $5 \%$, while the smaller, colinear VP2 protein constitutes the remaining bulk of the virion (Cotmore et al., 1986). Parvoviruses are characterized by a surprisingly high rate of evolutionary changes; at approximately $10^{-4} \mathrm{nt}$ substitution per site per year, which is more typical for RNA viruses (Sackelton and Holmes, 2006). Alignment of VP2 capsid protein gene sequences of parvoviruses and their comparison with known molecular structures allowed a first structural prediction of the B19V capsid shell with help of cryoelectron microscopy and crystallographic X-ray diffraction studies on VP2-only (Chapman and Rossmann, 1993).

Virus like particles (VLPs) of B19V were obtained from recombinant systems such as baculovirus (Agbandje et al., 1991, 1994; Kaufman et al., 2004). More recently, native virions, either DNA-containing or empty, have been purified and crystallized, and their structure has been compared to that of VP2-only VLPs (Kaufman et al., 2008). The capsid shell is composed of 60 protein subunits; the core structure is formed by the VP common region, forming classical beta-barrel, with eight strands connected by large loops projecting on the outer surface and determining its topography and specific structures at the 5-, 3-, and 2-fold symmetry axes. Similar to other parvoviruses, a cylindrical structure is present at the 5-fold axis, forming a gated channel connecting interior and outer surface of the virion, whose rim is surrounded by a "canyon-like" depression. Typical of B19V is the absence of prominent spikes at the 3-fold axis and a general rounded, smooth surface. When comparing VP2 VLPs with native virions, difference in structure is mainly evident around the 5 -fold axis, suggesting that in native virions, either DNAcontaining or empty, the cylindrical channel is normally bordered by the N-termini of VP2 proteins (Giorgio, 2013). Inside the capsid is the ssDNA genome. At the $5^{\prime}$ and $3^{\prime}$ ends of this genome are palindromic sequences of approximately 120 to $250 \mathrm{nt}$ that form hairpins and are essential for viral genome replication. 
The NSP is 671aa polypeptide $(74 \mathrm{kDa})$, containing an SF3 helicase domain. In NSPs of small viruses (such as parvovirus, polyomavirus, and papillomavirus), a SF3 helicase domain usually hybridizes with the viral origin of replication (OR) domain to prime DNA replication, leading to the OR unwinding, necessary for priming of strand displacement synthesis (Ozawa and Young, 1987). The cellular replication proteins are then recruited to the origin and the viral DNA is replicated. It can be assumed that its activity is also necessary for strand unwinding in the packaging phase of replicative cycle. NSP transactivates its own promoter, boosting viral macromolecular synthesis and promoting viral replication (Raab et al., 2002; Guan et al., 2009). The representative presentation is shown in Fig. 1.

Structure of several SF3 helicases has been solved, but not that of B19V NS protein. They all possess the same core alpha/beta fold, consisting of a five-stranded parallel beta sheet flanked on both sides by several alpha helices. The SF3 helicase proteins assemble into a hexameric ring (Doerig et al., 1999; Zhi et al., 2006).

Despite the fact that B19V NSP is of nuclear localization, produced early during replication and being detectable along the course of infection, it is not associated with virions like other NS proteins of parvoviruses (Cotmore et al., 1986). It has been shown that NS protein is present in infected cells in other forms with lower molecular mass, but neither posttranslational modification nor processing of these forms of NS has been clearly documented. (Cotmore et al., 1986; Ozawa and Young, 1987). As discussed earlier, structural and functional predictions indicate the presence of DNA binding, endonuclease, helicase, and transactivating domains. Some of these activities have been documented experimentally. NS protein is essential for replication of B19V genome (Luo and Astell, 1993; Sol et al., 1993) by operating on terminal structures of B19V DNA replicative intermediates, allowing terminal resolution and strand unwinding, necessary for priming of strand displacement synthesis (Arend and Dayer, 1990). On the whole, the NS1 protein of parvovirus $\mathrm{B} 19$ is a multifunctional protein that performs many different functions during the virus life cycle.

\section{Functional genomics of the B19 virus}

Heterologous transactivation of several genes such as those involved in inflammatory responses have been attributed to NSP (Fu et al., 2002). Expression of NSP in heterologous cellular systems, such as K562 cells, can promote production of the inflammatory cytokine interleukin 6 (IL-6), but neither the production of other related cytokines, as IL-1 $\beta$, IL-8, nor TNF- $\alpha$ (Sol et al., 1999). NSP-primed IL-6 induction is mediated by a NF- $\mathrm{kB}$ binding site in the IL- 6 promoter region, which is strongly implying that NSP func- tions as a transacting transcriptional activator on the IL-6 promoter (Ozawa et al., 1988). In a different system, such as the monocytic cell line U937, expression of a transduced NSP gene can induce the production of TNF- $\alpha$ mRNA as well as protein in a manner associated with the NSP expression. The AP- 1 and AP- 2 motifs on the TNF- $\alpha$ promoter are responsible for this NSP-mediated upregulation (Momoeda et al., 1994). Despite the diverse cellular environments, both mechanisms indicate a potential proinflammatory role of NSP (Moffatt et al., 1998).

B19V NSP shows various effects on the host cells. Early reports indicated its cytotoxicity that could be abolished by mutating its putative nucleoside triphosphate-binding domain (Nikkari et al., 1995; Brian et al., 2011). In addition, NS1 of parvovirus B19 induces cell death by apoptosis in at least erythroid-lineage cells by a pathway that involves caspase 3, whose activation may be a key event during NS1-induced cell death. Studies on UT7/EpoS1 and K562 cells have shown that NS1 initiates apoptosis by activating caspase 3 (but not caspase 1) in a manner which is deferent from the IL-6 activation pathway (Moffatt et al., 1998; Ozawa et al., 1988). In human erythroid progenitors, CD36+ cells, infection-induced DNA fragmentation characteristic of apoptosis, and the commitment of erythroid cells to undergo apoptosis was combined with their accumulation in the G(2) phase of the cell cycle. The cytotoxicity of NS1 in such cells results from chromosomal DNA damage caused by the DNA-nicking and DNA-attaching activities of NS1. Studies have been shown NS1 covalently binds to cellular DNA and is modified by PARP (Poly ADP ribose polymerase), an enzyme involved in repairing single-stranded DNA nicks. The DNA nick repair pathway initiated by PARP and the DNA repair pathways initiated by ATM/ATR are necessary for efficient apoptosis resulting from NS1 expression (Poole et al., 2011; Momoeda et al., 1994). NS1-induced apoptosis was inhibited by caspase 3, 6, and 8 inhibitors, and substantial caspase 3 , 6 , and 8 activities were induced by NS1 expression. Fas-FasL interaction was not involved in induction of apoptosis in erythroid cells, but these cells were sensitized to apoptosis induced by TNF- $\alpha$, suggesting a possible connection between the respective apoptotic pathways activated by TNF- $\alpha$ and NS1 in human erythroid cells (Levy et al., 2009). Model for B19V NS1 induction of anti-DNA antibodies resulting in apoptosis is shown in Fig. 2.

\section{B19 virus receptor and internalization}

It was proved that $\mathrm{B} 19 \mathrm{~V}$ binding to the cellular receptor globoside (Gb4Cer) induces structural changes in the capsid, leading to the accessibility of the N-terminal region of VP1 (VP1u). Although such large receptor-induced structural changes have not yet been observed in other parvoviruses, 


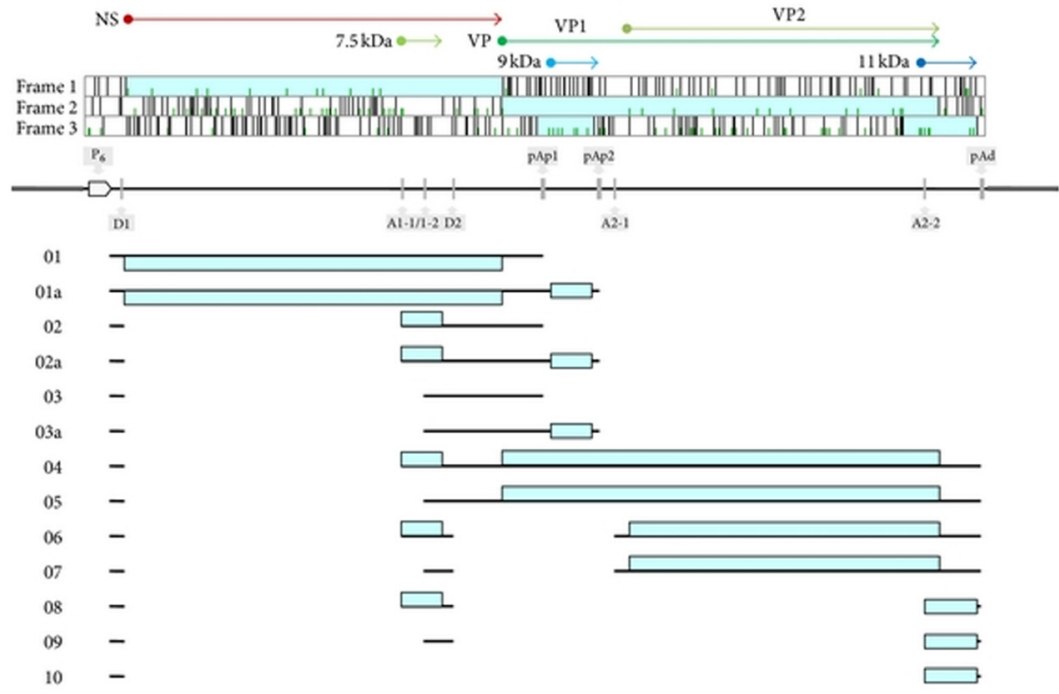

Fig. 1

Schematic representation of $\mathrm{B} 19 \mathrm{~V}$ genome organization and functional mapping

Top: open reading frames identified in the positive strand of the genome; arrows indicate the coding regions for viral proteins positioned on the ORF map. Center: genome organization, with distinct representation of the terminal and internal regions and indication of the positions of promoter (P6), splice donor (D1, D2), splice acceptor (A1-1/2, A2-2/2), and cleavage-polyadenylation (pAp1, pAp2, and pAd) sites. Bottom: viral mRNAs species; black boxes indicate the exon composition and light boxes indicate the ORFs contained within mRNAs (Giorgio, 2013).

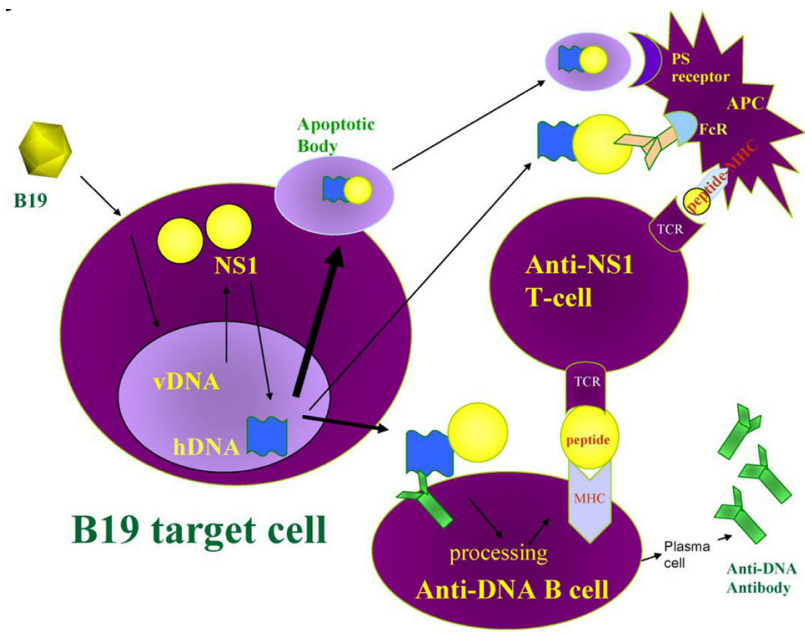

Fig. 2

Model for B19V NS1 induction of anti-DNA antibodies $\mathrm{B} 19 \mathrm{~V}$-induced apoptosis generates nucleosomes and apoptotic bodies containing NS1-modified DNA. Anergized anti-DNA B cells take up NS1modified nucleosomal DNA through their anti-DNA immunoglobulin surface receptor and present NS1 peptides in the context of MHC to NS1specific $\mathrm{T}$ cells. The NS1 specific T cells are activated by antigen presenting cells (APC) that express NS1 peptides in the context of surface MHC after uptake of apoptotic bodies or immune complexes containing NS1-modified DNA. The NS1-specific T cells provide the helper signal required, in addition to the DNA signal, for the anergized $\mathrm{B}$ cell to break tolerance. $\mathrm{vDNA}=$ viral DNA; $\mathrm{hDNA}=$ human DNA; $\mathrm{TC}=\mathrm{T}$ cell receptor; $\mathrm{PS}$ receptor $=$ phosphati dylserine receptor; $\mathrm{FcR}=\mathrm{Fc}$ receptor (Poole et al., 2011).

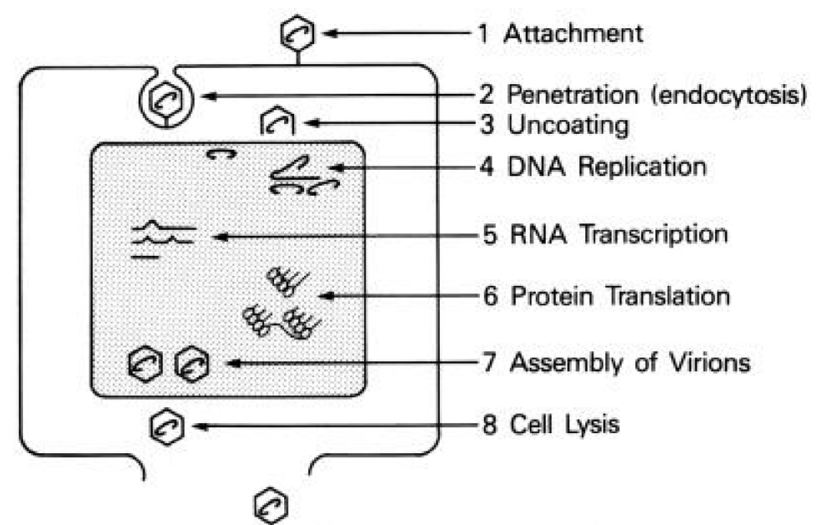

Fig. 3

Model for B19 life cycle (Heegard and Brown, 2002; Harbison et al., 2008) The life cycle of parvovirus B19 includes binding of the virus to host cell receptors (1), internalization (2), uncoating and translocation of the genome to the host nucleus (3), DNA replication (4), RNA transcription (5), protein translation (6), assembly of capsids and packaging of the genome (7), and finally cell lysis with the release of the mature virions (8). 
a slight opening of the 5-fold axis pore has been detected following binding of adeno-associated virus $2(\mathrm{AAV}-2)$ to heparin (Heegard and Brown, 2002). The expansion of the 5 -fold axis pore is believed to facilitate the externalization of VP1u, which, in all parvoviruses studied so far, occurs during the intracellular trafficking of the capsid mediated by the acidified endosomal environment (Mani et al., 2006; Parsyan et al., 2006; Harbison et al., 2008). Model for B19 life cycle is shown in Fig. 3.

\section{Epidemiology}

Based on seroprevalence studies, it has been demonstrated that human parvovirus $\mathrm{B} 19 \mathrm{~V}$ is actively circulating worldwide without neither ethnical nor geographical boundaries, albeit with some regional differences (Chorba et al., 1986; Brown et al., 2001; Mossong et al., 2008; Salimi et al., 2008; Molar-de Backer et al., 2012; Duedu et al., 2013). Acquisition is often during childhood and continues at lower rates throughout adulthood such that between 70 and $85 \%$ of adults show serologic evidence of past infection (Cohen and Buckley, 1988; Kelley et al., 2000). Infectivity is temperature-dependent, with the infection being more common in winter and spring. Transmission of infection usually occurs by inhalation of virus in aerosol droplets (Anderson et al., 1985). Infection can also be transmitted vertically from mother to fetus (Bonvicini et al., 2007) through transfusion of blood products, bone marrow transplants, and solid-organ transplants (Chorba et al., 1986; Arzi et al., 1999; Mossong et al., 2008; Heegard and Lamb, 2000 Broliden et al., 2001; Egbuna et al., 2006). The secondary attack risk for exposed household persons is about 50\%, and about half of that for classroom contacts (Chorba et al., 1986).

\section{Pathogenesis and immune response}

After gaining access to the human host, $\mathrm{B} 19 \mathrm{~V}$ targets the erythroid progenitors in the bone marrow by binding to the glycosphingolipid globoside (Gb4), also known as blood group P antigen (Brown et al., 2001). P antigen is expressed abundantly on erythroblasts and at lower levels in a limited number of other nonerythroid cell types. Although the $\mathrm{P}$ antigen is necessary for binding of the virus to the cell surface, it is not sufficient for entry and replicative infection in human cells (Chorba et al., 1986; Brown et al., 2001). Recent studies support the existence of a cellular co-receptor; a $5 \beta 1$ integrin, necessary for a successful infection, although this hypothesis remains controversial (Weigel-Kelly et al., 2003). This integrin is expressed at high levels on erythroid progenitors, whereas $\mathrm{P}$ antigen-positive non erythroid cells that do not express this co-receptor are considered non permissive for efficient infection. A third molecule, Ku80, has also been suggested as a possible co-receptor for B19V infection (Munataka et al., 2005).

After B19V infection of erythroid progenitors, cell death occurs either by lysis or by apoptosis (Takahashi et al., 1990; Morita et al., 2003) mediated by the NSP. In normal infection, intense viremia lasts several days, during which time the reticulocyte count can drop to zero (Kutzman et al., 1987). Recovery is associated with production of virus-specific IgM antibodies 10 to 12 days post infection. This is followed by the production of IgG antibodies that are directed against both types of viral capsid proteins (Modrow et al., 2002). It is discussed that antibodies to the unique amino terminal region of VP1 seem most important (Kutzman et al., 1988). It has been a long-held belief that the development of antibodies results in rapid and complete clearance of viremia. Emerging evidence, however, challenges this notion (Saikawa et al., 1993). With the use of sensitive quantitative techniques such as dot blot and nested PCR assays, B19V DNA has been detected in bone marrow and in peripheral blood for months and even years in seemingly immunocompetent individuals, despite the presence of neutralizing antibody (Soderland-Venermo et al., 2002; Lindblom et al., 2005). The clinical significance of this delayed clearance and low-level viremia is unknown.

Traditionally, the humoral immune response has been considered most important for clearance of parvovirus infection and for long-term protection from re-infection. However, accumulating data suggest that humoral immunity alone may be insufficient for virus eradication (Hsu et al., 2011). The cellular immune response is now attracting more attention, and its contribution to infection control is gaining appreciation. Although limited data are available, studies have shown a striking $\mathrm{CD}^{+} \mathrm{T}$ cell response mounted predominantly against B19V NSP (Tolfvestam et al., 2001). Moreover, activated $\mathrm{CD} 8^{+} \mathrm{T}$ cells against $\mathrm{B} 19$ epitopes have been detected for up to 2 years after infection, which may suggest that $\mathrm{T}$ cells contribute to long-term pathogen control (Isa et al., 2005). It is interesting that Isa et al. (2006) showed discordance between the distributions of the cellular immune response in healthy seropositive individuals compared with those having B19V persistence due to skewing of the $\mathrm{CD}^{+} \mathrm{T}$ cell response toward structural VP proteins (Norbeck et al., 2005). Thus, lack of B19V clearance could potentially be related to failure or perhaps "exhaustion" of the NSP response, however, this remains to be proved (Zhou et al., 2004). Less is understood about the role of $\mathrm{B} 19 \mathrm{~V}$-specific $\mathrm{CD}^{+} \mathrm{T}$ cells in acute infection, but it does seem that $\mathrm{CD}^{+} \mathrm{T}$ cell proliferative responses are directed against VP1 and VP2 (von Poblotzki et al., 1996; Fransila et al., 2001). Further studies are required to clarify the role of the cellular immune response in viral clearance, in establishment of persistent infection, and in relation to the clinical manifestations. 
Table 1. Complications post human parvovirus B19 infection

\begin{tabular}{|c|c|c|c|}
\hline Host susceptibility & Well-established syndromes & $\begin{array}{l}\text { Other associated symptoms based on } \\
\text { organ system }\end{array}$ & References \\
\hline $\begin{array}{l}\text { All patients especially } \\
\text { children }\end{array}$ & ${ }^{\star}$ Fifth Disease & $\begin{array}{l}\text { Renal: proliferative glomerulonephritis, } \\
\text { collapsing glomerulopathy, focal segmen- } \\
\text { tal glomerulosclerosis, thrombotic micro- } \\
\text { angiopathy, renal transplant dysfunction, } \\
\text { acute allograft rejection }\end{array}$ & $\begin{array}{l}\text { (Wierenga et al.,1995; Marchand et al., 1999; } \\
\text { Murer et al., 2000; Nakazawa et al., 2000; } \\
\text { Zalnourian et al., 2000; Taylor et al., 2001; } \\
\text { Basoun et al., 2002; Cavallo et al., 2003; On- } \\
\text { guru et al., 2006) }\end{array}$ \\
\hline Adult women & *Arthropathy & & (Luzzi and Kartz, 1985) \\
\hline $\begin{array}{l}\text { After maternal infec- } \\
\text { tion during pregnancy }\end{array}$ & $\begin{array}{l}{ }^{*} \text { Hydrops fetalis, intrauterine } \\
\text { fetal death, miscarriage (after } \\
\text { maternal infection during } \\
\text { pregnancy) }\end{array}$ & $\begin{array}{l}\text { Rheumatic: rheumatoid arthritis, systemic } \\
\text { lupus erythematosus, chronic fatigue syn- } \\
\text { drome, dermatomyositis, uveitis, systemic } \\
\text { sclerosis }\end{array}$ & (Kerr, 2000) \\
\hline $\begin{array}{l}\text { Patients with chronic } \\
\text { haemolytic disorder }\end{array}$ & $\begin{array}{l}{ }^{*} \text { Transient aplastic crisis (in pa- } \\
\text { tients with chronic hemolytic } \\
\text { disorders) }\end{array}$ & & (Kuhl et al., 2005) \\
\hline $\begin{array}{l}\text { Immunocompromised } \\
\text { patients }\end{array}$ & $\begin{array}{c}{ }^{*} \text { Chronic pure red blood cell } \\
\text { aplasia }\end{array}$ & $\begin{array}{l}\text { Cardiac: myocarditis, cardiomyopathy, } \\
\text { diastolic dysfunction }\end{array}$ & (Luzzi and Kartz, 1985; Kerr, 2000) \\
\hline All patients & & $\begin{array}{l}\text { Hepatobiliary: hepatitis, fulminant liver } \\
\text { failure }\end{array}$ & (Serjeant et al., 1981; Kuhl et al., 2005) \\
\hline$=$ & & $\begin{array}{l}\text { Hematologic: hemophagocytic syndrome, } \\
\text { idiopathic thrombocytopenic purpura and } \\
\text { hemolytic uremic syndrome }\end{array}$ & $\begin{array}{c}\text { (Diaz and Collazos, 2000; Bock, 2006; Ergaz } \\
\text { and Omoy, 2006) }\end{array}$ \\
\hline$=$ & & $\begin{array}{l}\text { Dermatologic: "Gloves and socks" syn- } \\
\text { drome, Gianotti-Crosti syndrome and } \\
\text { erythema nodosum [70 \& 83] }\end{array}$ & (Kerr, 2000; Onguru et al., 2006) \\
\hline$=$ & & $\begin{array}{l}\text { Vasculitis: Kawasaki disease, Henoch- } \\
\text { Schönlein purpura, microscopic polyar- } \\
\text { teritis nodosa and Wegener's granulomato- } \\
\text { sis }[90,91 \& 92]\end{array}$ & $\begin{array}{c}\text { (Mustafa and McClain, 1996; Aktepe et al., } \\
\text { 2004; So et al., 2007) }\end{array}$ \\
\hline$=$ & & $\begin{array}{l}\text { Neurologic: encephalopathy, meningitis, } \\
\text { seizures, transverse myelitis, Guillain- } \\
\text { Barre syndrome, acute cerebellar ataxia, } \\
\text { neuropathy }\end{array}$ & (Nigro et al., 1994; Lunardi et al., 2008) \\
\hline$=$ & & $\begin{array}{l}\text { Pulmonary: idiopathic pulmonary fibrosis, } \\
\text { scleroderma-associated pulmonary fibro- } \\
\text { sis, lymphocytic interstitial pneumonitis } \\
\text { and septal capillaritis }\end{array}$ & (Nigro et al., 1994) \\
\hline
\end{tabular}

${ }^{*}$ Five well-established syndromes that are associated with B19 infection are shown. In addition, a wide range of manifestations have been reported in association with this infection, but a causal role for B19V in many of these has not been conclusively established.

Table 2. Comparative analysis of the efficiency of different assays applied for the diagnosis of diseases caused by human parvovirus B19

\begin{tabular}{|c|c|c|c|c|}
\hline Disease & $\operatorname{IgM}$ & IgG & B19V DNA hybridization & B19V DNA amplification \\
\hline Fifth disease & +++ & ++ & - & + \\
\hline Arthropathy & ++ & + & - & + \\
\hline Transient aplastic crisis & $+/-$ & $+/-$ & ++ & ++ \\
\hline Persistent anemia & $+/-$ & $+/-$ & ++ & ++ \\
\hline Hydrops fetalis and congenital infection & $+/-$ & + & $+/-$ & ++ \\
\hline Previous infection & - & ++ & - & $+/-$ \\
\hline
\end{tabular}

(+) Positive results. (-) Negative results. Greater numbers of plus signs indicate stronger positive results. 


\section{Clinical manifestations and complications}

The spectrum of clinical disorders that are associated with $\mathrm{B} 19 \mathrm{~V}$ infection ranges from benign to life-threatening depending on the age, hematologic status, and immunologic status of the host (Lindblom et al., 2005b). Many immunocompetent individuals with detectable B19V-specific IgG have no recollection of specific symptoms or recall only nonspecific symptoms of the upper respiratory tract illness. There are several common and well-established outcomes of B19V infection (Lefrere et al., 2005). Erythema infectiosum, also referred to as fifth disease, is the most common manifestation of infection in children (Anderson, 1987). It is characterized by low-grade fever, malaise, a "slapped cheek" facial rash, and later by the spread of a lacy maculopapular rash involving the trunk and limbs. The rash normally disappears within 1 week, although recrudescence can occur for several months after emotional or physical stress or exposure to sunlight or heat (Musiani et al., 2005). Arthralgias and arthritis can occur in the setting of erythema infectiosum, but arthropathy is a more common manifestation of infection in adults, particularly in women (White et al., 1985). Sudden onset of symmetric polyarthralgia or polyarthritis with a rheumatoid-like distribution involving knees, wrists, ankles, and metacarpophalangeal joints are noted (Woolf et al., 1989). Although the joint symptoms are usually of brief duration, some do have prolonged symptoms that last weeks to years (Arend and Dayer, 1990). The pathogenesis of the cutaneous eruptions and joint symptoms are presumed to be, at least in part, due to deposition of immune complexes in skin and synovial tissue, because the onset of manifestations coincides with appearance of B19V-specific antibodies in the serum (Brass et al., 1982). Immunocompromised patients, who cannot mount an antibody response to B19V, typically do not develop these symptoms, whereas treatment of these patients with intravenous immunoglobulin may produce rash and/or joint pains. Nevertheless, other mechanisms besides immune complex deposition may be involved in the inflammatory response; skin biopsies from infected patients suggest that direct infection of dermal vessels and cellular infiltration may contribute to tissue injury (Takahashi et al., 1995; Magro et al., 2000). However, not all immunocompetent patients that mount an antibody response show symptoms. Other factors unique to the host likely play a role, such as elaboration of particular cytokine profiles (Kerr et al., 2003, 2004).

Transient aplastic crisis as a result of B19V infection is of particular concern in patients with either decreased red blood cell production or increased turnover (e.g. hereditary spherocytosis, sickle cell disease) (Serjeant et al., 1993; Choi et al., 2002). In healthy individuals, temporary suppression of erythropoiesis during the viremic phase is usually well tolerated owing to the long life span of erythrocytes (120 days), and hemoglobin levels remain fairly stable. In contrast, a severe and sometimes life-threatening drop in hemoglobin can occur in those having shortened red cell lifespan (5 to 15 days), as is the case with chronic hemolytic disorders (Opaleye et al., 2011). Although supportive care with transfusion is often required, the aplastic crisis is usually self-limiting, rarely lasting for more than two weeks, as a result of the production of neutralizing antivirus antibodies. Parvovirus B19 has been linked to other hematologic abnormalities: thrombocytopenia, leukopenia, or both may be seen in acute infection, even in immunologically normal hosts (Pattison et al., 1981). Cases of immune thrombocytopenic purpura, Henoch-Schonlein purpura and hemophagocytic syndrome have been attributed to parvovirus B19. However, transient erythroblastopenia of childhood and true aplastic anemia are not associated with infection (Brown, 2008). Finally, B19V infection during pregnancy may lead to hydrops fetalis and intrauterine fetal death (Ergaz and Omay, 2006).

\section{Diagnosis}

As discussed, $\mathrm{B} 19 \mathrm{~V}$ is a virus presenting different clinical syndromes, so that the acute-phase infection can be followed by a delayed clearance, active chronic infections, or silent persistence in tissues, depending on the interplay with host factors and the efficacy of the immune system response (Servey et al., 2007). Therefore, an accurate laboratory diagnosis of B19V infection will necessary rely on a multiparametric approach, combining as much as possible of both molecular detection of viral components and immunological detection of virus-specific antibodies (Corcoran and Doyle, 2004).

Immunologically, detection of a specific immune response is still considered the standard and most widely used means of laboratory diagnosis of B19V infection. Parallel detection of specific anti-B19 IgM and IgG antibodies is carried out and interpretation of the combination of results may allow for a presumptive diagnosis of active, recent, or past infection (Barah et al., 2003). Of limited availability, although potentially useful, are assays to determine IgG avidity or acute-phase ETS reactivity (Magro et al., 2006).

Historically, at the beginning of the studies on B19V, immunological assays were established using native virus as antigens, but very early on this limitation was overcome and the antigens used for immunological detection have been obtained by means of heterologous recombinant expression systems (Gallinella et al., 2003; Doyle, 2011). Recombinant proteins expressed in prokaryotic systems have been used for the detection of immunity against linear epitopes, since they lose their native conformation. On the other hand, the recombinant proteins expressed in eukaryotic system maintain their native conformation, and, thus, are used to 
detect immunity against conformational epitopes (Modrow and Dorsch, 2002). In particular, viral capsid proteins assembled as VLPs with antigenic configuration quite similar to that of native virus are the recognized standard antigens for immunological detection.

Recently developed chemiluminescent immunoassays can use VLPs composed of VP2 only, VP2+VP1, or $\mathrm{VP} 2+\mathrm{VP} 1 \mathrm{u}$ expressed in prokaryotic systems, thus allowing the detection of antibodies to conformational VP2 or also to linear VP1u epitopes. Western blot, or, better, line blot assays, includes an array of conformational and linear antigens and can be used as a confirmatory assay to dissect the range of antibody response to B19V (Cohen et al., 1983; Anderson et al., 1986). In this kind of assay, NSP can also be used as an antigen to detect the presence of specific antibodies, whose correlation with clinical course is, however, still controversial.

Molecularly, the detection of the viral genome in peripheral blood, bone marrow, or tissues can be considered the more direct and appropriate approach to the diagnosis of infection. In the progress towards a rapid and accurate molecular diagnosis, a wide array of molecular hybridization and nucleic acid amplification techniques have continuously been developed (Anderson et al., 1986; Kerr et al., 1999). In particular, standardization and inclusion of competitor or internal controls have been developed for PCR protocols in a continuous effort of accuracy and robustness (Kaikkonen et al., 1999; Manaresi et al., 2004; Enders et al., 2006). Nowadays, real-time quantitative, internally controlled PCR techniques must be considered the standard analytical method for the molecular detection of B19V (Zerbini et al., 1995; Gallinella et al., 1997; Peterlana et al., 2006; Musiani et al., 2007). Two main requirements should be met; first, the capability of detection of all genotypes of B19V; second, a calibrated and standardized quantification of viral target. Both of these requirements can take advantage of international standards and can be challenged by international proficiency panels (Aberham et al., 2001). The continuous technical development will certainly in the future lead to novel molecular detection methods and analytical platforms that will improve performances and reduce time and costs.

Finally, in situ hybridization techniques for the detection of viral nucleic acids, and immunohistochemical detection of viral proteins, can be useful as a complement to PCR techniques for investigation of viral infection in bioptic samples, with the advantage of identification of infected cells and allowing the discrimination of productive infections from silent persistence of the virus (Salimans et al., 1989; Morey et al., 1992; Gallinella et al., 1994, 2004; Gentilomi et al., 1994; Gruber et al., 2001; Manaresi et al., 2002; Baylis et al., 2012). The sensitivity of direct DNA hybridization methods is approximately 106 genome copies per milliliter, while the sensitivity of DNA amplification techniques (specifically PCR) is approximately 102 genome copies per milliliter (Anderson et al., 1985; Bonvicini et al., 2006).

\section{Treatment}

Specific antiviral therapy is not available to treat B19V infection. The treatment approach of infection depends on host factors such as immune status, underlying conditions, and manifestations of infection (Broliden, 2001). Most cases of infection in immunocompetent hosts do not need treatment, because the symptoms are transient, although nonsteroidal anti-inflammatory agents may be helpful in cases of arthropathy. Patients with transient aplastic crisis may need supportive therapy with blood transfusions until neutralizing antibody response can clear the virus and hematopoiesis is restored (Bonvicini et al., 2007). In cases of fetal infections and hydrops, intrauterine transfusions are indicated when the hemoglobin concentration in the fetal circulation falls below a threshold level, and case series report improved survival rates of hydropic fetuses (Morey et al., 1995; Bonvicini et al., 2006). There are several options for the treatment of pure red cell aplasia and persistent infection in immunocompromised patients, in whom B19V-specific antibody response is absent or minimal (Lunardi et al., 1998). Commercial Ig (IVIG), a significant source of anti-B19V antibodies, has proved to be efficacious, although no controlled studies have been carried out (Morey et al., 1995; Moudgil et al., 1997; Murer et al., 2000; Egbuna et al., 2006). Various regimens have been reported with favorable outcomes, but on the basis of the pooled data, $400 \mathrm{mg} / \mathrm{kg}$ per day for 5 to 10 consecutive days seems to be clinically useful in most cases. Although clinical response is common as evidenced by reticulocytosis, increased hemoglobin levels, and decline in serum viral DNA, a complete eradication of viremia may, however, not occur in some patients, particularly in transplant patients, who are highly immunosuppressed. Thus, relapses of anemia can occur up to several months after completion of treatment (Brennand and Cameron, 2008). Repeated administration of IVIG may be helpful, but some patients experience multiple relapses (Moudgil et al., 1997; Brennand and Cameron, 2008). Reduction of immunosuppressive medication is often recommended in addition to IVIG (or without IVIG in less severe cases) to allow the patient's own immune response to mature and neutralize the virus (Bertoni et al., 1997; Lamont et al., 2011). Several reports have concluded that symptomatic B19V infection is linked specifically to the use of tacrolimus rather than the overall state of immunosuppression (Grabarczyk et al., 2011). This is based on the observations that a switch from tacrolimus to cyclosporine was followed by viral clearance and complete resolution of anemia in some patients (Pamidi 
et al., 2000). Accordingly, some have suggested this change in drug regimen for infected recipients who fail to respond to IVIG. The mechanism for this difference, if it is real, remains unknown. Spontaneous recovery has also been reported in some patients without therapy (Taylor et al., 2001; Eid et al., 2006). Human monoclonal antibodies have been developed, but their therapeutic or prophylactic use has not been evaluated (Gigler et al., 1999; Geetha et al., 2000).

\section{Prevention and vaccine development}

Various strategies can be used to prevent B19V transmission in the community and in the hospital. Good hand washing is critical and the most important single method of infection control (Katragadda et al., 2013). Close contact with individuals who have respiratory symptoms or fever should be avoided when possible and frequent hand washing is advised (Leifeldt et al., 2002). Patients who have suspected $\mathrm{B} 19 \mathrm{~V}$ infection should be identified on admission and placed in isolation. Staff should be educated about the modes of spread of B19V and that shedding of virus typically lasts about 3 to 8 days, but may persist for weeks, particularly in immunosuppressed patients (Crabol et al., 2012). Blood and blood product should be carefully screened before transfusion into the recipient (Giorgio, 2013). The development of a vaccine for B19V has been a problematical endeavor. Preliminary work on vaccine development has been conducted. Main immunogenic determinants are considered the viral capsid proteins, with their VP2 conformational and VP1u linear epitopes. Viral capsid proteins expressed in eukaryotic heterologous systems will retain original structure and form VLPs that are antigenically similar to native virions. Therefore, VLPs can be produced and assembled from VP2 protein only or can be enriched in VP1 to include neutralizing epitopes encoded in the VP1u region in the vaccine (Geetha et al., 2000). These VLPs are immunogenic in the animal experimental model. Phase I studies showed their immunogenicity and relative safety in humans; however phase II studies showed a remarkable reactogenicity (Leifeldt et al., 2002; Crabol et al., 2012). These results still fuel the development of efficient and safer vaccines.

\section{Conclusions}

Parvovirus B19 infection is associated with a wide spectrum of clinical manifestations, some of which were well established and some still controversial. It is a virus that can offer continuous matter of interest to virologists for many reasons. The pattern of genetic evolution, its peculiar properties and functional profile, the characteristics of its narrow tropism and restricted replication, its complex relationship with the host and its ample pathogenetic potential are all topics that are far from a comprehensive understanding. The lack of efficient adaptation to in vitro tissue cultures and the absence of animal models have limited classical virological studies and made studies on B19V dependent on molecular biology. However, the difficulties in obtaining efficient recombinant systems have impaired a thorough understanding of the viral lifecycle and virus-host interactions.

$\mathrm{B} 19 \mathrm{~V}$ is underestimated from a clinical perspective. Its wide circulation and prevalent benign and self-limiting clinical course generally lead to a diminished appreciation of its pathogenetic potential. In this review, only selected clinical aspects have been discussed, despite the possibility that $\mathrm{B} 19 \mathrm{~V}$ is a potential etiological agent in a wider ensemble of diseases, encompassing practically all organs and systems. An extended awareness and definition of the actual pathogenetic role of $\mathrm{B} 19 \mathrm{~V}$ in the human diseases, the development of better diagnostic methods and algorithms, the development of prophylactic, and therapeutic options will continue to be relevant issues, worth of efforts by the scientific community.

\section{References}

Aberham C, Pendl C, Gross P, Zerlauth G, Gessner M (2001): A quantitative, internally controlled real-time PCR Assay for the detection of parvovirus B19 DNA. J. Virol. Methods 92, 183-191. http://dx.doi.org/10.1016/S01660934(00)00292-5

Agbandje M, Kajigaya S, MoKenna R, Young NS, Rossmann MG (1994): The structure of human parvovirus B19 at 8 A resolution. Virology 203, 106-115. http://dx.doi. org/10.1006/viro.1994.1460

Agbandje M, McKenna R, Rossmann MG, Kajigaya S, Young NS (1991): Preliminary X-ray crystallographic investigation of human parvovirus B19. Virology 184, 170-174. http:// dx.doi.org/10.1016/0042-6822(91)90833-W

Aktepe OC, Yetgin S, Olcay L, Ozbek N (2004): Human parvovirus B19 associated with idiopathic thrombocytopenic purpura. Pediatr. Hematol. Oncol. 21, 421-426. http:// dx.doi.org/10.1080/08880010490457141

Anderson LJ (1987): Role of parvovirus B19 in human disease. Pediatr. Infect. Dis. J. 6, 711-718. http://dx.doi. org/10.1097/00006454-198708000-00003

Anderson LJ, Tsou C, Parker RA (1986): Detection of antibodies and antigens of human parvovirus B19 by enzyme-linked immunosorbent assay. J. Clin. Microbiol. 24, 522-526.

Anderson MJ, Higgins PG, Davis LR, Willman JS, Jones SE, Kidd IM, Pattison JR, Tyrrell DA (1985): Experimental parvoviral infection in humans. J. Infect. Dis. 152, 257-265. http://dx.doi.org/10.1093/infdis/152.2.257

Arend WP, Dayer JM (1990): Cytokines and cytokine inhibitors or antagonists in rheumatoid arthritis. Arthritis Rheum. 33, 305-315. http://dx.doi.org/10.1002/art.1780330302 
Azzi A, Morfini M, Mannucci PM (1999): The transfusionassociated transmission of parvovirus B19. Transfus. Med. Rev. 13, 194-204. http://dx.doi.org/10.1016/S08877963(99)80033-9

Barah F, Vallely PJ, Cleator GM, Kerr JR (2003): Neurological manifestations of human parvovirus B19 infection. Rev. Med. Virol. 13, 185-199. http://dx.doi.org/10.1002/rmv.388

Barsoum NR, Bunnapradist S, Mougdil A, Toyoda M, Vo A, Jordan SC (2002): Treatment of parvovirus B-19 (PV B-19) infection allows for successful kidney transplantation without disease recurrence. Am. J. Transplant. 2, 425-428. http://dx.doi.org/10.1034/j.1600-6143.2002.20505.x

Baylis SA, Ma L, Padley DJ, Heath AB Yu MW (2012): Collaborative study to establish a World Health Organization International genotype panel for parvovirus B19 DNA nucleic acid amplification technology (NAT)-based assays. Vox Sang 102, 204-211. http://dx.doi.org/10.1111/j.14230410.2011.01541.x

Bertoni E, Rosati A, Zanazzi M, Azzi A, Zakrzewska K., Guidi S, Fanci R, Salvadori M (1997): Aplastic anemia due to B19 parvovirus infection in cadaveric renal transplant recipients: An underestimated infectious disease in the immunocompromised host. J. Nephrol. 10, 152-156.

Bock CT (2006): Parvovirus B19: A new emerging pathogenic agent of inflammatory cardiomyopathy. Ernst Schering Research Found Workshop, pp. 83-97.

Bonvicini F, Filippone C, Manaresi E (2006): Peptide nucleic acid-based in situ hybridization assay for detection of parvovirus B19 nucleic acids. Clin. Chem. 52, 973-978. http://dx.doi.org/10.1373/clinchem.2005.064741

Bonvicini F, Mirasoli M, Gallinella G, Zerbini M, Musiani M, Roda A (2007): PNA-based probe for quantitative chemiluminescent in situ hybridisation imaging of cellular parvovirus B19 replication kinetics. Analyst 132, 519-523. http://dx.doi.org/10.1039/b701664f

Brass C, Elliott LM, Stevens DA (1982): Academy rash, a probable epidemic of erythema infectiosum (fifth disease). JAMA 248, 568-572. http://dx.doi.org/10.1001/ jama.1982.03330050050030

Brennand J, Cameron A (2008): Fetal anaemia: diagnosis and management. Best. Pract. Res. Clin. Obstet. Gynaecol. 22, 1529. http://dx.doi.org/10.1016/j.bpobgyn.2007.08.005

Broliden K (2001): Parvovirus B19 infection in pediatric solidorgan and bone marrow transplantation. Pediatr. Transplant. 5, 320-330. http://dx.doi.org/10.1034/j.1399-3046 $.2001 .00035 . \mathrm{x}$

Brown KE (2008): Human Parvoviruses. In Long SS, Pickering LK, Prober CG (Eds): Principles and Practice of Pediatric Infectious Diseases. 3rd ed. Philadelphia, PA: Churchill Livingstone Elsevier, pp. 1072-1076. http://dx.doi. org/10.1016/B978-0-7020-3468-8.50220-0

Brown KE, Young NS, Alving BM, Barbosa LH (2001): Parvovirus B19 implications for transfusion medicine.Summary of a workshop. Transfusion 41, 130-135. http://dx.doi. org/10.1046/j.1537-2995.2001.41010130.x

Cavallo R, Merlino C, Re D, Bollero C, Bergallo M, Lembo D, Musso T, Leonardi G, Segoloni GP, Ponzi AN (2003): $\mathrm{B} 19$ virus infection in renal transplant recipients. J. Clin.
Virol. 26, 361-368. http://dx.doi.org/10.1016/S13866532(02)00104-X

Chapman MS, Rossmann MG (1993): Structure, sequence, and function correlations among parvoviruses. Virology 194, 491-508. http://dx.doi.org/10.1006/viro.1993.1288

Choi SH, Chang SP, Won JC, Lee JS, Chi HS, Yang WS, Park SK (2002): A case of persistent anemia in a renal transplant recipient: Association with parvovirus B19 infection. Scand. J. Infect. Dis. 34, 71-75. http://dx.doi. org $/ 10.1080 / 003655402753395247$

Chorba T, Coccia P, Holman RC (1986): The role of parvovirus B19 in aplastic crisis and erythema infectiosum (fifth disease). J. Infect. Dis. 154, 383-393. http://dx.doi.org/10.1093/ infdis/154.3.383

Cohen BJ, Buckley MM (1988): The prevalence of antibody to human parvovirus B19 in England and Wales. J. Med. Microbiol. 25,151-153. http://dx.doi. org/10.1099/00222615-25-2-151

Cohen BJ, Mortimer PP, Pereira MS (1983): Diagnostic assays with monoclonal antibodies for the human serum parvovirus like virus (SPLV). J. Hyg. 91, 113-130. http://dx.doi. org/10.1017/S0022172400060095

Corcoran A, Doyle S (2004): Advances in the biology, diagnosis and host-pathogen interactions of parvovirus B19. J. Med. Microbiol. 53, 459-475. http://dx.doi.org/10.1099/ imm.0.05485-0

Cossart YE (1981): Parvovirus B19 finds a disease. Lancet 2, 988989. http://dx.doi.org/10.1016/S0140-6736(81)91185-5

Cossart YE, Field AM, Cant B, Widdows D (1975): Parvovirus-like particles in human sera. Lancet 1, 72-73.

Cotmore SF, McKie VC, Anderson LJ (1986): Identification of the major structural and nonstructural proteins encoded by human parvovirus B19 and mapping of their genes by procaryotic expression of isolated genomic fragments. J. Virol. 60, 548-557.

Crabol Y, Terrier B, Rozenberg F, Pestre V, Legendre C, Hermine O, Montagnier-Petrissans C, Guillevin L (2012): Intravenous Immunoglobulin Therapy for Pure Red Cell Aplasia Related to Human Parvovirus B19 Infection: A Retrospective Study of 10 Patients and Review of the Literature. Clin. Infect. Dis. 56, 968-977. http://dx.doi. org $/ 10.1093 / \mathrm{cid} / \mathrm{cis} 1046$

De Jong EP, Walther FJ, Kroes AC, Oepkes D (2011): Parvovirus B19 infection in pregnancy: new insights and management. Prenat. Diagn. 31, 419-25. http://dx.doi. org/10.1002/pd.2714

Diaz F, Collazos J (2000): Hepatic dysfunction due to parvovirus B19 infection. J. Infect. Chemother. 6, 63-64. http:// dx.doi.org/10.1007/s101560050052

Doerig C, Hirt B, Antonietti JP, Beard P (1990): Nonstructural protein of parvoviruses B19 and minute virus of mice controls transcription. J. Virol. 64, 387-396.

Doyle S (2011): The detection of parvoviruses. Methods Mol. Biol. 665, 213-231. http://dx.doi.org/10.1007/978-1$\underline{60761-817-1 \quad 13}$

Duedu KO, Sagoe KWC, Ayeh-Kumi PF, Affrim RB, Adiku T (2013): The effects of co-infection with human parvovirus B19 and Plasmodium falciparum on type and degree 
of anaemia in Ghanaian children. Asian Pac. J. Trop. Biomed. 3, 129-139. http://dx.doi.org/10.1016/S22211691(13)60037-4

Egbuna O, Zand MS, Arbini A., Menegus M, Taylor J (2006): A cluster of parvovirus B19 infections in renal transplant recipients: A prospective case series and review of the literature. Am. J. Transplant. 6, 225-231. http://dx.doi. org/10.1111/j.1600-6143.2005.01139.x

Eid AJ, Brown RA, Patel R, Razonable RR (2006): Parvovirus B19 infection after transplantation: A review of 98 cases. Clin. Infect. Dis. 43, 40-48. http://dx.doi.org/10.1086/504812

Enders M, Schalasta G, Baisch C (2006): Human parvovirus B19 infection during pregnancy value of modern molecular and serological diagnostics. J. Clin. Virol. 35, 400-406. http://dx.doi.org/10.1016/j.jcv.2005.11.002

Ergaz Z, Ornoy A (2006): Parvovirus B19 in pregnancy. Reprod Toxicol. 21, 421-35. http://dx.doi.org/10.1016/j. reprotox.2005.01.006

Franssil R, Hokynar K, Hedman K (2001): T helper cell-mediated in vitro responses of recently and remotely infected subjects to a candidate recombinant vaccine for human parvovirus b19. J. Infect. Dis. 183, 805-809. http://dx.doi. org/10.1086/318819

Fu Y, Ishii KK, Munakata Y, Saitoh T, Kaku M, Sasaki T (2002): Regulation of tumor necrosis factor alpha promoter by human parvovirus B19 NS1 through activation of AP-1 and AP-2. J. Virol. 76, 5395-5403. http://dx.doi. org/10.1128/JVI.76.11.5395-5403.2002

Gallinella G, Bonvicini F, Filippone C (2004): Calibrated realtime PCR for evaluation of parvovirus B19 viral load. Clin. Chem. 50, 759-762. http://dx.doi.org/10.1373/ clinchem.2003.027292

Gallinella G, Young NS, Brown KE (1994): In situ hybridisation and in situ polymerase chain reaction detection of parvovirus B19 DNA within cells. J. Virol. Methods 50, 67-74. http:// dx.doi.org/10.1016/0166-0934(94)90164-3

Gallinella G, Zerbini M, Musiani M, Venturoli S, Gentilomi G, Manaresi E (1997): Quantitation of parvovirus B19 DNA sequences by competitive PCR: differential hybridization of the amplicons and immunoenzymatic detection on microplate. Mol. Cell. Probes 11, 127-133. http://dx.doi. org/10.1006/mcpr.1996.0095

Gallinella G, Zuffi E, Gentilomi G (2003): Relevance of B19 markers in serum samples for a diagnosis of parvovirus B19 correlated diseases. J. Med. Virol. 71, 135-139. http:// dx.doi.org/10.1002/jmv.10452

Geetha D, Zachary, JB, Baldado H M, Kronz JD Kraus ES (2000): Pure red cell aplasia caused by Parvovirus B19 infection in solid organ transplant recipients: A case report and review of literature. Clin. Transplant. 14, 586-591. http:// dx.doi.org/10.1034/j.1399-0012.2000.140612.x

Gentilomi G, Zerbini M, Musiani M (1993): In situ detection of B19 DNA in bone marrow of immunodeficient patients using a digoxigenin-labelled probe. Mol. Cell. Probes 7, 19-24. http://dx.doi.org/10.1006/mcpr.1993.1003

Gigler A, Dorsch S, Hemauer A (1999): Generation of neutralizing human monoclonal antibodies against parvovirus B19 proteins. J. Virol. 73, 1974-1979.
Giorgio G (2013): Parvovirus B19 Achievements and Challenges: Review. ISRN Virol. 2013, 1-33.

Grabarczyk P, Kalinska A, Kara M (2011): Identification and characterization of acute infection with parvovirus B19 genotype 2 in immunocompromised patients in Poland. J. Med. Virol. 83, 142-149. http://dx.doi.org/10.1002/ jmv.21947

Gruber F, Falkner FG, Dorner F, Hämmerle T (2001): Quantitation of viral DNA by real-time PCR applying duplex amplification, internal standardization, and two-color fluorescence detection. Appl. Environ. Microbiol. 67, 2837-2839. http://dx.doi.org/10.1128/AEM.67.6.2837-2839.2001

Guan W, Wong S, Zhi N, Qiu J (2009): The genome of human parvovirus B19 can replicate in nonpermissive cells with the help of adenovirus genes and produces infectious virus. J. Virol. 83, 9541-9553. http://dx.doi.org/10.1128/ JVI.00702-09

Harbison CE, Chiorini JA, Parrish CR (2008): The parvovirus capsid odyssey: from the cell surface to the nucleus. Trends Microbiol. 16, 208-214. http://dx.doi.org/10.1016/j. $\underline{\text { tim.2008.01.012 }}$

Heegaard ED, Brown KE (2002): Human Parvovirus B19. Clin. Microbiol. Rev. 15, 485-505 http://dx.doi.org/10.1128/ CMR.15.3.485-505.2002

Heegaard ED, Laub PB (2000): Parvovirus B19 transmitted by bone marrow. Br. J. Haematol. 111, 659-661. http://dx.doi. org/10.1046/j.1365-2141.2000.02407.x

Hokynar K, Soderlund-Venermo M, Pesonen M, Ranki A, Kiviluoto O, Partio EK, Hedman K (2002): A new parvovirus genotype persistent in human skin. Virology 302, 224-228. http://dx.doi.org/10.1006/viro.2002.1673

Hsu GJ, Tzang BS, Tsai CC, Chiu CC, Huang CY, Hsu T (2011): Effects of human parvovirus B19 on expression of defensins and Toll-like receptors. Chin. J. Physiol. 54, 367-376.

Isa A, Kasprowicz V, Norbeck O, Loughry A, Jeffery K., Broliden K, Klenerman P, Tolfvenstam T, Bowness P (2005): Prolonged activation of virus-specific CD8+T cells after acute B19 infection. PLoS Med. 2, e343. http://dx.doi. org/10.1371/journal.pmed.0020343

Isa A, Norbeck O, Hirbod T, Lundqvist A, Kasprowicz V, Bowness P, Klenerman P, Broliden K, Tolfvenstam T (2006): Aberrant cellular immune responses in humans infected persistently with parvovirus B19. J. Med. Virol. 78, 129-133. http://dx.doi.org/10.1002/jmv.20514

Jordan JA (1996): Identification of human parvovirus B19 infection in idiopathic nonimmune hydrops fetalis. Am. J. Obstet. Gynecol. 174, 37-42. http://dx.doi.org/10.1016/S00029378(96)70370-8

Kahn JS, Kesebir D, Cotmore SF (2008): Seroepidemiology of human bocavirus defined using recombinant viruslike particles. J. Infect. Dis. 198, 41-50. http://dx.doi. org/10.1086/588674

Kaikkonen L, Lankinen H, Harjunpää I (1999): Acute phase specific heptapeptide epitope for diagnosis of parvovirus B19 infection. J. Clin. Microbiol. 37, 3952-3956.

Katragadda L, Shahid Z, Restrepo A, Muzaffar J, Alapat D, Anaissie E (2013): Preemptive intravenous immunoglobulin allows safe and timely administration of antineoplastic therapies 
in patients with multiple myeloma and parvovirus B19 disease. Transpl. Infect. Dis. 15, 354-60. http://dx.doi. org/10.1111/tid.12067

Kaufmann B, Chipman PR, Kostyuchenko VA Modrow S, Rossmann MG (2008): Visualization of the externalized VP2 N termini of infectious human parvovirus B19. J. Virol. 82, 7306-7312. http://dx.doi.org/10.1128/JVI.00512-08

Kaufmann B, Simpson AA, Rossmann MG (2004): The structure of human parvovirus B19. Proc. Natl. Acad. Sci. USA 101, 11628-11633. http://dx.doi.org/10.1073/ pnas.0402992101

Kelly HA, Siebert D, Hammond R, Leydon J, Kiely P, Maskill W (2000): The age-specific prevalence of human parvovirus immunity in Victoria, Australia, compared with other parts of the world. Epidemiol. Infect. 124, 449-457. http:// dx.doi.org/10.1017/S0950268899003817

Kerr JR (2000): Pathogenesis of human parvovirus B19 in rheumatic disease. Ann. Rheum. Dis. 59, 672-683. http://dx.doi. org/10.1136/ard.59.9.672

Kerr JR, Cunniffe VS, Kelleher P, Coats AJ, Mattey DL (2004): Circulating cytokines and chemokines in acute symptomatic parvovirus B19 infection: Negative association between levels of pro-inflammatory cytokines and development of B19-associated arthritis. J. Med. Virol. 74, 147- 155 http://dx.doi.org/10.1002/jmv.20158

Kerr JR, McCoy M, Burke B, Mattey DL, Pravica V, Hutchinson IV (2003): Cytokine gene polymorphisms associated with symptomatic parvovirus B19 infection. J. Clin. Pathol. 56, 725-727. http://dx.doi.org/10.1136/jcp.56.10.725

Kerr S, O'Keeffe V, Kilty C, Doyle S (1999): Undenatured parvovirus B19 antigens are essential for the accurate detection of parvovirus B19 IgG. J. Med. Virol. 57, 179-185. http://dx.doi.org/10.1002/(SICI)1096-9071(199902)57:2<179::AID-JMV16>3.0.CO;2-T

Kuhl U, Pauschinger M, Seeberg B, Lassner D, Noutsias M, Poller W, Schultheiss HP (2005): Viral persistence in the myocardium is associated with progressive cardiac dysfunction. Circulation 112, 1965-1970. http://dx.doi.org/10.1161/ CIRCULATIONAHA.105.548156

Kurtzman GJ, Gascon P, Caras M, Cohen B, Young NS (1988): B19parvovirus replicates in circulating cells of acutely infected patients. Blood 71, 1448-1454.

Kurtzman GJ, Ozawa K., Cohen B, Hanson G, Oseas R, Young NS (1987): Chronic bone marrow failure due to persistent parvovirusinfection. N. Engl. J. Med. 317, 287-294. http:// dx.doi.org/10.1056/NEJM198707303170506

Lamont RF, Sobel JD, Vaisbuch E (2011): Parvovirus B19 infection in human pregnancy. BJOG 118, 175-186. http://dx.doi. org/10.1111/j.1471-0528.2010.02749.x

Lefrére JJ, Servant-Delmas A, Candotti D (2005): Persistent B19 infection in immunocompetent individuals: implications for transfusion safety. Blood 106, 2890-2895. http:// dx.doi.org/10.1182/blood-2005-03-1053

Levy HC, Bowman VD, Govindasamy L, McKenna R, Nash K., Warrington K., Chen W, Muzyczka N, Yan X, Baker TS, Agbandje McKenna M (2009): Heparin binding induces conformational changes in adeno-associated virus se- rotype 2. J. Struct. Biol. 165, 146-156. http://dx.doi. org/10.1016/j.jsb.2008.12.002

Liefeldt L, Buhl M, Schweickert B, Engelmann E, Sezer O, Laschinski P, Preuschof L, Neumayer HH (2002): Eradication of parvovirus B19 infection after renal transplantation requires reduction of immunosuppression and high-dose immunoglobulin therapy. Nephrol. Dial. Transplant. 17, 1840-1842. http://dx.doi.org/10.1093/ndt/17.10.1840

Lindblom A, Isa A, Norbeck O, Wolf S, Johansson B, Broliden K, Tolfvenstam T (2005): Slow clearance of human parvovirus B19 viremia following acute infection. Clin. Infect. Dis. 41, 1201-1203. http://dx.doi.org/10.1086/444503

Lunardi C, Tinazzi E, Bason C, Dolcino M, Corrocher R, Puccetti A (2008): Human parvovirus B19 infection and autoimmunity. Autoimmun. Rev. 8, 116-120. http://dx.doi. org/10.1016/j.autrev.2008.07.005

Lunardi C, Tiso M, Borgato L (1998): Chronic parvovirus B19 infection induces the production of anti-virus antibodies with autoantigen binding properties. Eur. J. Immunol. 28, 936-48. http://dx.doi.org/10.1002/(SICI)1521-4141(199803)28:03<936::AID-IMMU936>3.0.CO;2-X

Luo W, Astell CR (1993): A novel protein encoded by small RNAs of parvovirus B19. Virology 195, 448-455. http://dx.doi. org/10.1006/viro.1993.1395

Luzzi GA, Kurtz JB (1985): Human parvovirus arthropathy and rheumatoid factor (Letter). Lancet 1, 1218. http://dx.doi. org/10.1016/S0140-6736(85)92899-5

Magro CM, Dawood MR, Crowson AN (2000): The cutaneous manifestations of human parvovirus B19 infection. Hum. Pathol. 31, 488-497. http://dx.doi.org/10.1053/ hp. 2000.6714

Magro CM, Wusirika R, Frambach GE, Nuovo GJ, Ferri C, Ross P Jr (2006): Autoimmune-like pulmonary disease in association with parvovirus B19: A clinical, morphologic, and molecular study of 12 cases. Appl. Immunohistochem. Mol. Morphol. 14, 208-216. http://dx.doi.org/10.1097/01. pai.0000160730.54062.6d

Manaresi E, Gallinella G, Venturoli S, Zerbini M, Musiani M (2004): Detection of parvovirus B19 IgG: choice of antigens and serological tests. J. Clin. Virol. 29, 51-53. http://dx.doi.org/10.1016/S1386-6532(03)00088-X

Manaresi E, Gallinella G, Zuffi E, Bonvicini F, Zerbini M, Musiani M (2002): Diagnosis and quantitative evaluation of parvovirus B19 infections by real-time PCR in the clinical laboratory. J. Med. Virol. 67, 275-281. http:// dx.doi.org/10.1002/jmv.2218

Mani B, Baltzer C, Valle N, Almendral J. M, Kempf C, Ros C (2006): Low $\mathrm{pH}$-dependent endosomal processing of the incoming parvovirus minute virus of mice virion leads to externalization of the VP1 N-terminal sequence (N-VP1), $\mathrm{N}-\mathrm{VP} 2$ cleavage, and uncoating of the full-length genome. J. Virol. 80, 1015-1024. http://dx.doi.org/10.1128/ JVI.80.2.1015-1024.2006

Marchand S, Tchernia G, Hiesse C, Tertian G, Cartron J, Kriaa F, Boubenider S, Goupy C, Lecointe D, Charpentier B (1999): Human parvovirus B19 infection in organ transplant recipients. Clin. Transplant. 13, 17-24. http://dx.doi. org/10.1034/j.1399-0012.1999.t01-1-130103.x 
Meryl W, Jeffrey BK (2007): Parvovirus B19 and the Kidney. Clin. J. Am. Soc. Nephrol. 2, S47-S56. http://dx.doi. org/10.2215/CJN.01060307

Modrow S, Dorsch S (2002): Antibody responses in parvovirus B19 infected patients. Pathol. Biol. 50, 326-331. http:// dx.doi.org/10.1016/S0369-8114(02)00302-4

Moffatt S, Tanaka N, Tada K (1996): A cytotoxic nonstructural protein, NS1, of human parvovirus B19 induces activation of interleukin-6 gene expression. J. Virol. 70, 8485-8491.

Moffatt S, Yaegashi N, Tada K, Tanaka N, Sugamura K (1998): Human parvovirus B19 nonstructural (NS1) protein induces apoptosis in erythroid lineage cells. J. Virol. 72, 3018-3028.

Molenaar-de Backer MW, Lukashov VV, van Binnendijk RS, Boot HJ, and Zaaijer HL (2012): Global co-existence of two evolutionary lineages of parvovirus B19 1a, different in genome-wide synonymous positions. PLoS One 7, e43206. http://dx.doi.org/10.1371/journal.pone. 0043206

Momoeda M, Wong S, Kawase N, Young S, Kajigaya S (1994): A putative nucleoside triphosphate-binding domain in the nonstructural protein of B19 parvovirus is required for cytotoxicity. J. Virol. 68, 8443-8446.

Morey AL, Porter HJ, Keeling JW, Fleming KA (1992): Nonisotopic in situ hybridisation and immunophenotyping of infected cells in the investigation of human fetal parvovirus infection. J. Clin. Pathol. 45, 673-678. http:// dx.doi.org/10.1136/jcp.45.8.673

Morey AL, Ferguson DJP, Fleming KA (1995): Combined immunocytochemistry and non-isotopic in situ hybridization for the ultrastructural investigation of human parvovirus B19 infection. Histochem. J. 27, 46-53. http://dx.doi. org/10.1007/BF00164171

Morita E, Nakashima A, Asao H, Sato H, Sugamura K (2003): Human parvovirus B19 nonstructural protein (NS1) induces cell cycle arrest at G(1) phase. J. Virol. 77, 2915-2921. http://dx.doi.org/10.1128/JVI.77.5.2915-2921.2003

Mossong J, Hens N, Friederichs V (2008): Parvovirus B19 infection in five European countries: seroepidemiology, force of infection and maternal risk of infection. Epidemiol. Infect. 136, 1059-1068. http://dx.doi.org/10.1017/ $\underline{\mathrm{S} 0950268807009661}$

Moudgil A, Shidban H, Nast CC, Bagga A, Aswad S, Graham SL, Mendez R, Jordan SC (1997): Parvovirus B19 infectionrelated complications in renal transplant recipients: Treatment with intravenous immunoglobulin. Transplantation 64, 1847-1850. http://dx.doi.org/10.1097/00007890199712270-00037

Munakata Y, Saito-Ito T, Kumura-Ishii K, Huang J, Kodera T, Ishii T, Hirabayashi Y, Koyanagi Y, Sasaki T (2005): Ku80 autoantigen as a cellular coreceptor for human parvovirus B19 infection. Blood 106, 3449-3456. http://dx.doi. org/10.1182/blood-2005-02-0536

Murer L, Zacchello G, Bianchi D, Dall'Amico R, Montini G, Andreetta B, Perini M, Dossi EC, Zanon G, Zacchello F (2000): Thrombotic microangiopathy associated with parvovirus B19 infection after renal transplantation. J. Am. Soc. Nephrol. 11, 1132-1137.
Musiani M, Gallinella G, Venturoli S, Zerbini M (2007): Competitive PCR ELISA protocols for the quantitative and the standardized detection of viral genomes. Nat. Protoc. 2, 2511-2519. http://dx.doi.org/10.1038/nprot.2007.312

Musiani M, Manaresi E, Gallinella G, Cricca M, Zerbini M (2005): Recurrent erythema in patients with long-term parvovirus B19 infection. Clin. Infect. Dis. 40, e117-e119. http:// dx.doi.org/10.1086/430442

Mustafa MM, McClain KL (1996): Diverse hematologic effects of parvovirus B19 infection. Pediatr. Clin. North Am. 43 809-821. http://dx.doi.org/10.1016/S00313955(05)70434-X

Nakazawa T, Tomosugi N, Sakamoto K, Asaka M, Yuri T, Ishikawa I, Kitagawa S (2000): Acute glomerulonephritis after human parvovirus B19 infection. Am. J. Kidney Dis. 35, E31. http://dx.doi.org/10.1016/S02726386(00)70070-9

Nguyen QT, Sifer C, Schneider V, Allaume X, Servant A, Bernaudin F, Auguste V, Garbarg-Chenon A (1999): Novel human erythrovirus associated with transient aplastic anemia. J. Clin. Microbiol. 37, 2483-2487.

Nigro G, Zerbini M, Krzysztofiak A, Gentilomi G, Porcaro MA, Mango T, Musiani M (1994): Active or recent parvovirus B19 infection in children with Kawasaki disease. Lancet 343, 1260-1261. http://dx.doi.org/10.1016/S01406736(94)92154-7

Nikkari S, Roivainen A, Hannonen P, Möttönen T, Luukkainen R, Yli-Jama T, Toivanen P (1995): Persistence of parvovirus B19 in synovial fluid and bone marrow. Ann. Rheum. Dis. 54, 597-600. http://dx.doi.org/10.1136/ard.54.7.597

Norbeck O, Isa A, Pöhlmann C (2005): Sustained CD8+T-cell responses induced after acute parvovirus B19 infection in humans: J. Virol. 79, 12117-12121. http://dx.doi. org/10.1128/JVI.79.18.12117-12121.2005

Onguru P, Dede F, Bodur H, Ayli D, Akinci E, Cevik MA, Kilic A (2006): Glomerulonephritis associating parvovirus B19 infection. Ren. Fail. 28, 85-88. http://dx.doi.or$\mathrm{g} / 10.1080 / 08860220500461302$

Opaleye OO, Fagbami AH, Lalremruata A, Kun JF (2011): Prevalence and association of human parvovirus B19V with hepatitis B and C viruses in Nigeria. J. Med. Virol. 83, 710-716. http://dx.doi.org/10.1002/jmv.22008

Ozawa K, Young N (1987): Characterization of capsid and non capsid proteins of B19 parvovirus propagated in human erythroid bone marrow cell cultures. J. Virol. 61, 2627-2630.

Ozawa K, Ayub J, Kajigaya S, Shimada T, Young N (1988): The gene encoding the nonstructural protein of B19 (human) parvovirus may be lethal in transfected cells. J. Virol. 62, 2884-2889.

Pamidi S, Friedman K., Kampalath B, Eshoa C, Hariharan S (2000): Human parvovirus B19 infection presenting as persistent anemia in renal transplant recipients. Transplantation 69, 2666-2669. http://dx.doi.org/10.1097/00007890200006270-00030

Parsyan A, Kerr S, Owusu-Ofori S, Elliott G, Allain JP (2006): Reactivity of genotype specific recombinant proteins of human 
erythrovirus B19 with plasmas from areas where genotype 1 or 3 is endemic. J. Clin. Microbiol. 44, 1367-1375. http:// dx.doi.org/10.1128/JCM.44.4.1367-1375.2006

Pattison JR, Jones SE, Hodgson J, Davis LR, White JM, Stroud CE, Murtaza L (1981): Parvovirus infections and hypoplastic crisis in sickle-cell anaemia. Lancet 1, 664-665. http:// dx.doi.org/10.1016/S0140-6736(81)91579-8

Peterlana D, Puccetti A, Corrocher R, Lunardi C (2006): Serologic and molecular detection of human parvovirus B19 infection. Clin. Chim. Acta 372, 14-23. http://dx.doi. org/10.1016/j.cca.2006.04.018

Poole BD, Kivovich V, Gilbert L, Naides SJ (2011): Parvovirus B19 Nonstructural Protein Induced Damage of Cellular DNA and Resultant Apoptosis. Int. J. Med. Sci. 8, 88-96. http://dx.doi.org/10.7150/ijms.8.88

Raab U, Beckenlehner K, Lowin T (2002): NS1 protein of parvovirus B19 interacts directly with DNA sequences of the p6 promoter and with the cellular transcription factors Sp1/Sp3. Virology 293, 86-93. http://dx.doi.org/10.1006/ viro.2001.1285

Sabella C, Goldfarb J (1999): Parvovirus B19 infections. Am Fam Physician. 60, 1455-1460.

Sackelton LA, Holmes EC (2006): Phylogenetic evidence for the rapid evolution of human B19 erythrovirus. J. Virol. 76, 9124.

SaikawaT, Anderson S, Momoeda M, Kajigaya S, Young NS (1993): Neutralizing linear epitopes of B19 parvovirus cluster in the VP1 unique and VP1-VP2 junction regions. J. Virol. 67, 3004-3009.

Salimans MMM, VandeRijke FM, Raap AK, van Elsacker-Niele AMW (1989): Detection of parvovirus B19 DNA in fetal tissues by in situ hybridisation and polymerase chain reaction. J. Clin. Pathol. 42, 25-530. http://dx.doi. org/10.1136/jcp.42.5.525

Salimi V, Gouya MM, Esteghamati AR, Safaie A, Heshmat R, Saadatmand Z, Mokhtari-Azad T (2008): Seroepidemiology of Human Parvovirus B19 in 5-25 Year Old Age People in Iran. Iran J. Public. Health 37, 19-25.

Serjeant G R, Topley JM, Mason K, Serjeant BE, Pattison JR, Jones SE (1981): Outbreak of aplastic crises in sickle cell anaemia associated with parvovirus-like agent. Lancet 2, 595-597. http://dx.doi.org/10.1016/S0140-6736(81)92739-2

Serjeant GR, Serjeant BE, Thomas PW, Anderson MJ, Patou G, Pattison JR. (1993): Human parvovirus infection in homozygous sickle cell disease. Lancet 341, 1237-1240, http://dx.doi.org/10.1016/0140-6736(93)91145-C

Servant A, Laperche S, Lallemand F, Marinho V, De Saint Maur G, Meritet JF, Garbarg-Chenon A (2002): Genetic diversity within human erythroviruses: Identification of three genotypes. J. Virol. 76, 9124-9134. http://dx.doi. org/10.1128/JVI.76.18.9124-9134.2002

Servey JT, Reamy BV, Hodge J (2007): Clinical presentations of parvovirus B19 infection. Am. Fam. Physician. 75, 373-376.

So K, Macquillan G, Garas G, Delriviere L, Mitchell A, Speers D, Mews C, Augustson B, de Boer WB, Baker D, Jeffrey GP (2007): Urgent liver transplantation for acute liver failure due to parvovirus B19 infection complicated by primary
Epstein-Barr virus and cytomegalovirus infections and aplastic anaemia. Intern Med J. 37, 192-195. http:// dx.doi.org/10.1111/j.1445-5994.2006.01293.x

Soderlund-Venermo M, Hokynar K, Nieminen J, Rautakorpi H, Hedman K (2002): Persistence of human parvovirus B19 in human tissues. Pathol Biol. 50, 307-316. http://dx.doi. org/10.1016/S0369-8114(02)00307-3

Sol N, Le Junter L, Vassias I, Freyssinier JM, Thomas A, Frigent AF, Rudkin BB, Fichelson S, Morinet F (1999): Possible interactions between the NS-1 protein and tumor necrosis factor alpha pathways in erythroid cell apoptosis induced by human parvovirus B19. J. Virol. 73, 8762-8770.

Sol N, Morinet F, Alizon M, Hazan U (1993): Trans-activation of the long terminal repeat of human immunodeficiency virus type 1 by the parvovirus B19 NS1 gene product. J. Gen. Virol. 74, 2011-2014. http://dx.doi. org/10.1099/0022-1317-74-9-2011

Takahashi M, Ito M, Sakamoto F, Shimizu N, Furukawa T, Takahashi M, Matsunaga Y (1995): Human parvovirus B19 infection: Immunohistochemical and electron microscopic studies of skin lesions. J. Cutan Pathol. 22, 168-172. http://dx.doi.org/10.1111/j.1600-0560.1995.tb01402.x

Takahashi T, Ozawa K, Takahashi K, Asano S, Takaku F (1990): Susceptibility of human erythropoietic cells to B19 parvovirus in vitro increases with differentiation. Blood 75, 603-610.

Taylor G, Drachenberg C, Faris-Young S (2001): Renal involvement of human parvovirus B19 in an immunocompetent host. Clin. Infect. Dis. 32, 167-169. http://dx.doi. org/10.1086/317556

Tolfvenstam T, Oxenius A, Price DA, Shacklett BL, Spiegel HM, Hedman K, Norbeck O, Levi M, Olsen K, Kantzanou M, Nixon DF, Broliden K, Klenerman P (2001): Direct ex vivo measurement of CD8 (+) T-lymphocyte responses to human parvovirus B19. J. Virol. 75, 540-543. http:// dx.doi.org/10.1128/JVI.75.1.540-543.2001

von Poblotzki A, Gerdes C, Reischl U, Wolf H, Modrow S (1996): Lymphoproliferative responses after infection with human parvovirus B19. J. Virol. 70, 7327-7330.

Weigel-Kelley KA, Yoder MC, Srivastava A (2003): Alpha5beta1 integrin as a cellular coreceptor for human parvovirus B19: Requirement of functional activation of beta1 integrin for viral entry. Blood 102, 3927-3933. http:// dx.doi.org/10.1182/blood-2003-05-1522

White DG, Woolf AD, Mortimer PP, Cohen BJ, Blake DR, Bacon PA(1985): Human parvovirus arthropathy. Lancet 1, 419 421. http://dx.doi.org/10.1016/S0140-6736(85)91145-6

Wierenga KJ, Pattison JR, Brink N, Griffiths M, Miller M, Shah DJ, Williams W, Serjeant BE, Serjeant GR (1995): Glomerulonephritis after human parvovirus infection in homozygous sickle-cell disease. Lancet 346, 475-476. http://dx.doi.org/10.1016/S0140-6736(95)91324-6

Woolf AD, Campion GV, Chishick A, Wise S, Cohen BJ, Klouda PT, Caul O, Dieppe PA (1989): Clinical manifestations of human parvovirus B19 in adults. Arch. Intern. Med. 149, 1153-1156. http://dx.doi.org/10.1001/archinte. 1989.00390050111022 
Young NS, Brown KE (2004): "Parvovirus B19". N. Engl. J. Med. 350, 586-597. http://dx.doi.org/10.1056/NEJMra030840

Zerbini M, Gibellini D. Musiani M, Venturoli S, Gallinella G, Gentilomi G (1995): Automated detection of digoxigenin labelled B19 parvovirus amplicons by a capture hybridization assay. J. Virol. Methods 55, 1-9. http://dx.doi. org/10.1016/0166-0934(95)00038-V

Zhi N, Mills IP, Lu J, Wong S, Filippone C, Brown KE (2006): Molecular and functional analyses of a human parvovirus B19 infectious clone demonstrates essential roles for NS1, VP1, and the 11-kilodalton protein in virus replication and infectivity. J. Virol. 80, 5941-5950. http:// dx.doi.org/10.1128/JVI.02430-05
Zhou S, Ou R, Huang L, Price GE, Moskophidis D (2004): Differential tissue-specific regulation of antiviral CD8+ T-cell immune responses during chronic viral infection. J. Virol, 78, 3578-3600. http://dx.doi.org/10.1128/JVI.78.7.3578$\underline{3600.2004}$

Zolnourian ZR, Curran MD, Rima BK, Coyle PV, O'Neill HJ, Middleton D (2000): Parvovirus B19 in kidney transplant patients. Transplantation 69, 2198-2202. http://dx.doi. org/10.1097/00007890-200005270-00043 